\title{
THE APPLICATION OF SCHOOL BASED MANAGEMENT IN IMPROVING STUDENT LEARNING OUTCOMES IN MADANI ISLAMIC JUNIOR HIGH SCHOOL ALAUDDIN PAO-PAO
}

\author{
Kasmawati \\ Faculty of Education and Teacher Training \\ UIN Alauddin Makassar \\ Jln H. M. Yasin Limpo No. 36 Samata Gowa \\ Email: kasmawati6131@gmail.com
}

\begin{abstract}
This article deals with the application of schoolbased management in Madani Islamic Junior High School (called madrasah tsanawiyah) at Pao-Pao. The main objective of this is to find out whether the application of school-based management can improve student learning outcomes in MTS Madani Alauddin Pao-Pao. The qualitative research is employed by the researcher, with a multidisciplinary approach. To obtain data, the authors do it with interview techniques, observation, and documentation to test the validity of the data using triangulation techniques. The results showed MTS Madani Alauddin Pao-pao, Gowa Regency, has implemented, but in practice it has not been maximized. This is because they still need ongoing assistance from competent parties. And still need assistance in the form of physical and non-physical from all relevant stakeholders so as to facilitate the implementation of MBS in Mts Madani Alauddin Pao-Pao (2) MTS Madani Alauddin Pao-pao, Gowa Regency, has an effort to improve student learning outcomes by: a ) provide a final assessment of the learning process that is carried out repeatedly, b) Provide an interesting learning method. In addition the teacher provides opportunities for students to work and participate in competitions or academic and nonacademic olympiads, c) Provide motivation to students (3) In achieving the vision and mission of the school the application
\end{abstract}


of school-based management can improve student learning outcomes in MTS Madani Alauddin Pao-Pao, Gowa Regency.

Keywords: School Based Management, Motivation, Learning Process,

\section{Introduction}

Education plays a crucial thing in improving world and human progress. It is also a long term investment in developing human resources, where increasing skills and abilities are considered as supporting factors to strive for humans to navigate an uncertain life.

Thus, education is strongly necessary and is considered as a basic need for Indonesian people who have a very wide area, education is needed as the key to future development. This means that both as educators, education staff, the community, and the state are expected to be able to move every individual to improve the quality of their existence and be able to participate in the development movement. The power of reform is essentially sourced from qualified human resources, and has a vision, transparency, and foresight that not only improve themselves in their groups, but always prioritize the interests of the nation and state in various lives.

Increasing human resources is an absolute prerequisite for achieving development goals. One vehicle to improve the quality of human resources is education so that the quality of education in Indonesia today still revolves around the issue of 
equal opportunity, relevance, quality, efficiency and effectiveness of education.

In accordance with the main problem and paying attention to the issues and challenges faced at the present time and future trends, it is necessary to create superior education, namely education that can develop students' potential and capacity optimally.

Education is a human endeavor (educator) with the responsibility of guiding students toward maturity, as a business that achieves certain goals and ideals naturally if implicitly it has a problem assessing the results of the effort, because every time people need to know (by reason various) to what extent the desired goals and ideals have been realized or implemented in the efforts that have been carried out.

Based on this understanding, it can be concluded that the role of education and guidance of children is directed towards the development of the formation of personality and character of children, talents, mental and physical abilities to reach the fullest potential, development of respect for parents and elderly people, cultural identity and values -own values of national values where the child originates and resides and respect for civilizations that are different from their own civilization. In addition, children are prepared to be responsible in a free society in the spirit of understanding, tolerance, friendship, friendship among fellow ethnic groups, national groups and fostering respect for the environment.

Education is the result of a mutual work that goes on in human life. Syaiful Sagala put in Webster's New World 
Dictionary; "Education is a training process for developing knowledge, skills, thoughts, characters and so on, especially through formal schooling".

In the laws of the Republic of Indonesia Chapter 1 Article 1 Paragraph 1 No. 20 of 2003 concerning the National Education System explained that;

Education is a conscious effort planned to create a learning atmosphere and learning process so that students actively develop their potential to have spiritual spiritual strength, self-control, personality, noble intelligence and skills needed by themselves, society, nation and country.

Based on the description that education is very important because education is a determinant of the quality of Human Resources. Today the superiority of a nation is no longer marked by the abundance of natural wealth, but on the superiority of Human Resources (HR). Sember Quality Human resources (HR) are positively correlated with the quality of education, the quality of education is often indicated by good conditions, fulfilling requirements, and all components that must be contained in education, these components are input, process, output, education staff, facilities and infrastructure and costs.

Allah swt stated in Qoran S. Ar Ra'd ayat 11

Translation:

Surely Allah does not change the state of a people so that they change the conditions that exist in themselves. 
M. Quraish Shihab interprets that in fact Allah does not change the state of a people, does not change the misery experienced by a people, becomes happiness so that the people themselves first change what is in themselves, believe in obtaining additional favours they must become better.

From the verse above, it can be concluded that if the Indonesian Nation wants to make changes, especially through education, then the people of Indonesia can change. Especially through education, of course those who can make changes are people who are competent and experts in their fields.

So far, the chaotic order of life of society has been the result of an economic system that is not strong, and consequently has brought the nation's people to a prolonged crisis. The crisis that occurs in various fields of life actually comes from the low, quality, ability, and morale of the teaching staff.

Thus, school-based management (SBM) is presented as a manifestation of a change in the system (reform) of education. The term reform itself is equated with a revolution in terms of massive changes. This is a reform and education development system that is more dominated by the government. Where the development of education by the government does have to be overhauled because it proves to be less effective, efficient and productive. Thus it can be stated that some of the characteristics of reform in certain fields, namely the power of unsatisfactory conditions in the past, the desire to improve them. 
The Efforts to decentralize education autonomy have basically long been championed by the education community. Therefore, the autonomy of education is strongly required to improve advanced as well as the quality of Indonesia education. Improving the quality of education is not a task that is often carried out because it is not only related to technical problems, but includes a variety of very complex and complex problems, both concerning planning, organizing, implementing, and also monitoring funding and the efficiency and effectiveness of the school system.

Therefore, education is now faced with regional autonomy that demands the management of autonomous education with a school-based "school-based management" management model. School-based management is a strategic alternative for improving the quality of education so that it can contribute to improving the quality and quality of education as a whole.

In order to realize the ideals and goals of National Education, the school implements education formally, because the school is a place where objects of knowledge, skills and ethics can be provided by educators. Achievement of this maximum target can be fulfilled if the educational institution is well managed, meaning that the existing institution is handled by people who have competence, ability and care in shaping the scientific dimension. Especially those who are directly involved in handling students in the learning process. Teachers who have the duty, obligation and responsibility to teach and educate. 
The implementation of basically school-based management effectively and efficiently has been carried out in Madrasah Tsanawiyah Madani, Gowa Regency. Head of Mardrasah Tsanawiyah Madani Alauddin Pao-Pao is demanded to have leadership abilities, planning and organizing, implementing and evaluating in educational institutions. In the preparation and implementation of management, the head of Madrasah Tsanawiyah Mandani must have professional skills and improve and establish good cooperation with work partners, in this case administrative staff, educative staff and organizing systems related to education to improve the quality of schools Madrasah Tsanawiyah Madani alauddin pao-pao Gowa Regency.

Pao-Pao Madrasah Tsanawiyah Madani Gowa Regency is one manifestation of the madrasa education system in South Sulawesi which continues to strive to improve its management model in improving management quality so that it has implications for the improvement of student learning outcomes. Madrasas in the eastern part of Indonesia in the past decade have continued to show their existence. As stated, researchers want to get more information about the relationship between the success applied by school principals in improving the School Based Management (SBM) system to carry out their role in an effective and efficient learning process as well as supporting the success of students in an educational institution. In fact, the implementation of School Based Management (SBM) must strive to develop and manage the education system with maximum quality so that it 
can exist, and be able to answer the challenges of the times in religious, national and state life.

Based on the background above, the writer is interested in studying further and conducting research under the title: "School-Based Management Implementation in improving student learning outcomes in MTS Madani Alauddin Pao-Pao, Gowa Regency".

\section{Theoretical Framework}

\section{School based management}

Management is the process of planning, organizing, application, to supervision by utilizing the resources involved in achieving the goals that have been set. The term schoolbased management which is a translation of the School Baset Management, first appeared in the United States of America the relevance of education to the demands and development of local communities in the community in the 1970s. (Nanang Fattah, 2003:19)

Suparlan argues that, school-based management is a strategy to improve schools by increasing decision-making authority significantly from the state and district to individual school education units. School-based management provides principals, teachers, students, and parents of students, to oversee the educational process by providing responsibility for taking on budget, personal and curriculum. (Suparlan, 2013:49).

Whereas school-based management according to Suparman is the secrecy of resources carried out 
independently by the school by involving all interest groups directly related to the school in the decision-making process to understand the school's quality needs or to achieve school quality goals in national education. (Eman Suparman, 2002:1)

Some of the opinions above give the understanding that school-based management is the management of schools that involve school people starting from school principals, educators, education staff, students, guardians of students to collaborate in the success of the vision that has been planned together and carry out missions and support each other so that the goals school quality in national education can be achieved.

\section{Learning Outcomes}

Achievement which means the results achieved (from what has been done or done). Learning achievement means mastery of knowledge or skills developed by subjects, usually indicated by test scores or numbers given by the teacher.

While according to Warsinto defines learning outcomes is that learning outcomes and activities are characterized by a change in behavior towards a positive relative to someone who is learning. (Depdiknas,2006:125).

Relationship with learning outcomes, Winarno provides an explanation that learning outcomes are "results achieved by someone from various educational interaction experiences, from which the classification of results that need to be possessed by a student, such as results in the form of concepts, and in the form of attitudes " (Winarno Surakhmad, 2003:75) 
Learning outcomes of students can be influenced by several factors including the following:

a) Internal factors

b) Physical Factors

Physical factors have a major influence on individual learning processes anytime and anywhere, physical in general and sensory devices in particular, as well as limbs, weak bodies, fatigue will cause attention impossible to carry out the perfect learning activities. a) Psychological factors

Psychological factors are psychiatric factors or an inner atmosphere which includes the learners when the assessment of learning outcomes of joyful atmosphere and moody atmosphere or thoughts that are in a good state of direct or indirect will be able to influence students who are being measured and in the value of learning outcomes. (Anas Sudjono, 2001:45).

a) Intelligence

Intelligence can be interpreted as a psychophysical ability to receive stimuli or adjustments to the environment in the right way. So, previous intelligence is not just a matter of brain quality but the quality of other body organs, but it must be admitted that the role of the brain in relation to human interaction is more prominent than other body organs because the brain is "manara controller", almost as long as human activity. (Muhibbin Syah, 2000:14).

b) Interest

In simple interest means a tendency and high enthusiasm or a big desire for something, for example students who have a great interest in mathematics will focus more attention than 
other students, thus allowing students to study harder and finally achieve the desired achievement.

c) Motivation

There are two approaches used to review and understand motivation: (1) motivation is seen as a knowledge process that helps the teacher explain the behavior observed and predict the behavior of others, (2) determine the characteristics of this process based on clues it can be believed if it appears to be used to predict and explain its behavior.

d) Talent

Talent is one of the human abilities to carry out an activity and has existed since humans existed. This is close to the problem of intelligence which is a mental structure that gives birth to the ability to understand something. (Oemar Hamalik, 2005:106)

a. External Factor

1. Social Environment

The school's social environment such as teachers, administrative staff, and classmates can influence students' learning enthusiasm. Teachers who often address sympathetic attitudes and behaviors and show good and diligent examples, especially in terms of learning.

2. Non-social Environment

Factors including the non-social environment are buildings, schools and the location of the student's family's home and location, learning tools, weather conditions and study time used by students. This factor is considered to determine the level of student learning success. 
The author can draw conclusions that the learning outcomes of students are the effects of what has been obtained after the learning process, these results can be known from the form of concepts, and in the form of positive attitudes of students, as for these things are influenced by external and internal factors that can expected to be able to improve student learning outcomes and can prevent obstruction of learning.

\section{Research Methods}

\section{Location and type of research}

This study took place at MTs Madani Alauddin Pao-pao, Gowa Regency. The type of research used is qualitative research. Qualitative research will produce descriptive data in the form of written words from people, phenomena, events, social activities, attitudes, beliefs, perceptions and thoughts of individuals individually or in groups. (Sugiono: 2009:9).

\section{Object of Research}

The intended research subject is the source where we obtain research information. The subjects in this study were principals, vice principals, educators and education staff. The object of research is the problem under study. The object of this study is the application of school-based management in improving student learning outcomes. The selection of MTs Madani Alauddin Pao-pao in Gowa Regency was based on the consideration that Gs-Madani Alauddin MTs Madani Alauddin had data needed for the preparation of this study. 


\section{Research Approach}

This study uses a multidisciplinary approach, a multidisciplinary approach is an approach in solving a problem using various perspectives and relevant knowledge, so that it can answer the problems given in this study as clearly as possible.

\section{Results and Discussion}

\section{Application of SBM at MTs Madani Alauddin Pao-pao, Gowa Regency}

Based on the results of the study, at MTs Madani Alauddin Pao-pao, Gowa District has conducted SBM (school-based management). This can be proven through the author's observation and interview, where it was found that some SBM concepts were implemented in the school but the SBM implementation was not maximal and still need assistance. Although the school has been independent in managing school affairs, school independence is the authority of the school to regulate and manage the interests of school members according to their own initiatives based on the aspirations of the school community in accordance with the applicable national education legislation. there are many benefits that can be felt by both the local government and the schools that are directly targeted by SBM. But there are still many obstacles or obstacles in the implementation of SBM. This is due to the lack of assistance in the implementation of programs, and inadequate facilities and infrastructure, the lack of available funds is also a barrier to the implementation of 
SBM in the school. Financial problems are a fairly basic problem at school. Because all components of education in schools are closely related to the school's financial components. Although not entirely, financial problems will directly affect the quality of schools, especially with regard to facilities and infrastructure as well as learning resources. Many schools are not able to carry out teaching and learning activities to the fullest, only because of financial problems, both to hire teachers and to provide good learning facilities and infrastructure.

As for the enactment of regional autonomy, the development of MBS has demanded that there be a change in school settings, including financial management, in processing finances must be carried out by adhering to a transparent, accountable, responsible, relevant, effective and efficient system.

When the principle of school-based management (SBM is implemented adheres to democratic, transparent, professional and accountable principles. Through the implementation of this program the managers of education in schools including school principals, teachers, school committees and local community leaders must be actively involved in each stage of the activity. This is the learning process that takes place and all parties provide mutual support for the progress of the school.

The application of the concept of school-based management to aspects of the school curriculum can already be seen from the policies provided by the government to 
schools regarding ownership of the school in accordance with school needs and orientation, and the authors found that the implementation of SBM in accordance with curriculum expectations and concepts and curriculum development teaching program, so that the learning process can run smoothly and in accordance with expectations.

This is in accordance with the author's observation, that the implementation of learning at MTs Madani Alauddin Pao-pao in Gowa Regency refers to the development of the 2013 criculum, and also examines the annual program preparation (PROTA), semester programming (PROSEM), and preparation of learning plans (RPP) until in the learning process.

In curriculum management, to achieve maximum results, the development of students' abilities is not only through extracurricular activities, but also through extracurricular activities that are managed in an integrated manner, of course, with the involvement of school members in achieving curriculum goals and educational goals.

Increasing community participation in education development. The participation can be known to be 7 . These levels are (1) Participation that uses available services, (2) Participation by contributing funds, materials, and labor, (3) Passive participation, which means accepting what decided by the school (school committee), (4) participation through consultation, (5) participation in services, (6) participation as executors of delegated / delegated activities, and (7) participation in decision making. 
With the participation of the community it is very helpful for the school to advance MTs Madani Alauddin Paopao in the Regency of Gowa in the future. This proves that with the participation and concern of the community towards the development of schools, community participation and the active participation of members of the school committee, the school can develop according to curriculum development and mutual expectations.

Each activity requires accountability. Many experiences that state that schools are managed openly and are ready to cooperate, will invite sympathy so that the community will be happy to provide the support or assistance needed by the school in an effort to improve education services for their children.

In managing funds in the school, the concept of transparency (openness) has been implemented, this is evidenced by the use of funds written on the transparency board of funds at MTs Madani Alauddin Pao-pao, Gowa Regency.

As for the implementation of SBM in achieving the school's vision and mission, as well as the benefits obtained after implementing SBM, with autonomy, schools can manage their resources by developing and implementing school-based management in accordance with the culture, conditions and needs of the school as well as the local community, freedom in managing the resources in question providing positive values for the development of future education and improving the quality of education. 
With the implementation of school-based management, schools are free to hold activities that are beneficial to students in achieving educational goals.

\section{School Efforts in Improving Learning Outcomes}

Learning outcomes are abilities possessed by students after they receive the learning experience ". (Nana Sudjana, 2010:22). Whereas according to Warsito define learning outcomes as follows:

From the definition above, it can be concluded that learning outcomes are the results achieved by students in the process of following learning activities by bringing a change and formation of one's behavior.

Associated with student learning outcomes can be seen specifically on the component or part of the description of the focus of the second variable about student learning outcomes. The student learning outcomes include the effectiveness of student output consisting of several indicators:

1) Results in the form of acquisition of students and the dynamics of the school system

2) Change of attitude

In the results of the acquisition of students and the dynamics of the school system, there are many efforts made so that students have good learning outcomes.

Recording the learning achievement of MTs Madani Alauddin Pao-pao students can be seen from two parts, namely a list of grades and a report card. Every teacher at 
school will teach by making preparations and rules first so that the teaching and learning process can take place effectively and achieve maximum results. Rule making is one way to improve learning outcomes. The willingness of students to obey or deny the rules there are consequences that must be accepted by each student. If students obey all rules and will get something positive, that is a gift. Conversely, if you deny the rules that exist, they will receive something negative, namely in the form of punishment. Conclusions that can be taken from efforts to improve student learning outcomes are:

a. Learning outcomes are an assessment of the learning process carried out, so that it can change the mindset of students.

b. The learning methods carried out are of two types, namely the lecture method and the discussion method.

c. Factors that influence learning outcomes are biological and psychological factors, as well as environmental factors around us.

d. In assessing learning outcomes can be seen from three aspects, namely cognitive, affective, and psychomotor.

\section{Application of school-based management}

BPPN in collaboration with the World Bank (1999) has examined several factors that need to be considered in connection with the implementation of SBM. These factors are:

a. School Obligations 
SBM that offers flexibility in managing schools has great potential in creating school principals, teachers, and managers of the professional education system. Therefore, the implementation needs to be accompanied by a set of obligations, monitoring and high demands for accountability (accountable). Thus, schools are required to be able to display resource management in a transparent, democratic, without monopoly, and are responsible for both the community and the government, in order to increase the service capacity of students.

\section{b. Government Policies and Priorities}

The government as the person in charge of national education has the right to formulate policies that become national priorities, especially those related to literacy and numeracy improvement programs, efficiency, quality and educational equity. The government also needs to formulate a general set of guidelines on the implementation of SBM to ensure that student outcomes are evaluated properly, government policies are implemented effectively, schools are operated within a government-approved framework, and the budget is spent in accordance with the objectives.

c. The Role of Parents and Communities

MBS demands the support of a skilled and qualified workforce to generate motivation for more productive work and empower local authorities, as well as streamline the system and eliminate overlapping bureaucracies through community participation, parents and school councils.

d. The Role of Professionalism and Managerial 
Principals, teachers and administrative staff must have deep knowledge of students and the principles of education to ensure that all important decisions made by schools are based on educational considerations. The principal needs to learn about government policies and school priorities themselves. He must :

1) Having the ability to collaborate with teachers and the community around the school.

2) Having broad understanding and insight into the theory of education and learning;

3) Having the ability and skills to analyze the current situation based on what should be and be able to predict future events based on the current situation;

4) Having the willingness and ability to identify problems and needs related to the effectiveness of education in schools;

5) Able to take advantage of various opportunities, make opposition as an opportunity, and conceptualize new directions for change.

e. Professional Development

In order for schools to obtain the benefits offered by SBM, there needs to be a professional development center, which functions as a provider of training services for education staff for SBM

The principal is a manager in the school, who is responsible for planning, implementing, and evaluating changes or improvements to teaching programs in the school. There are four steps that must be taken, namely assessing the 
suitability of existing programs with the culture and needs of students, improving program planning, choosing and implement the program, and assess program changes. This was done so that the implementation of SBM could be implemented smoothly at Alauddin Pao-pao's MTs Madani.

With the implementation of school-based management at Alauddin Pao-pao's MTs Madani, schools can hold activities that are beneficial for students in achieving educational goals. But that goal will be missed if all parties are willing to cooperate and the competent parties carry out continuous assistance.

\section{Conclusion}

Based on the results of the research along with the analysis process, conclusions can be taken as follows:

a. MTs Madani Alauddin Pao-pao, Gowa Regency, has implemented SBM, but in its implementation it has not been maximized This is because it still requires continuous assistance, besides the lack of funds owned by the school so that there are some things that are not maximal. MTs Madani Alauddin Pao-pao has implemented programs.

b. MTs Madani Alauddin Pao-pao has efforts to improve student learning outcomes are:

1. Provide a final assessment of the learning process carried out so that it can change the mindset of each student. As for assessing learning outcomes can be seen from three aspects, namely knowledge, attitudes, and skills. 
2. Provide interesting learning methods. In addition, the teacher provides opportunities for students to work and participate in competitions or academic or non-academic olympiad, as well as follow religious practices such as caring for bodies, tadarrus and others. So that the output is expected to have skills that can be applied in social life.

3. Provide motivation to students. Because actually the factors that influence learning outcomes are factors from within humans (biological and psychological) and factors from outside of human beings, namely environmental factors around us.

4. In achieving the school's vision and mission the application of school-based management can improve student learning outcomes, and the benefits obtained after applying SBM are with the existence of autonomy, schools can manage their resources by developing and implementing school-based management in accordance with culture, circumstances, and school needs also the local community. However, this goal will be carried out if all parties are willing to cooperate and competent parties carry out continuous assistance.

\section{REFERENCES}

Arikunto. Suharsimin,( 2006) Prosedur Penelitian,Jakarta: Rineke Cipta.

Atmosudirdjo, Prajudi, (1982) Administrasi dan Manjemen Umum, Jakarta: Ghalia Indonesia. 
Aswan Zain. Syaiful Bahri Djamarah, (2006) Strategi Pembelajaran, Jakarta: Rineka Cipta

Andini T Nirmala, Aditia A Pratama, kamus Lengkap Bahasa Indonesia.

Besse, Wawancara, Tgl 2 Agustus 2018 di MTs Madani Alauddin Pao-pao

Depertemen Pendidikan Nasional.( 2007) Undang-Undang Sistem Pendidikan Nasional.Cet. IV; Jakarta: Sinar Grafia.

Departemen Pendidikan Nasional, Modul DIKLAT, Manajemen Pemberdayaan Sumber Daya Tenaga Pendidik dan Kependidikan Sekolah, tahun 2008.

Depertemen Agama Republik Indonesia,( 1989) Al-Quran dan Terjamahanya (Surabaya: Mahkota,.

Depdiknas,( 2006) Bunga Rampai Keberbasilan Guru dalam Pembelajaran (SMA, SMK, dan SLB). Jakarta: Depdiknas,

Dekdikbut, (1999)Kamus Besar Bahasa Indonesia, Jakarta: Balai Pustaka.

Engkoswara,(2011), Administrasi Pendidikan, Cet, II: Bandung: Alfabeta.

Fattah, Nanang, (2003) Konsep MBS dan Dewan Sekolah, (Bandung: C.V Pustaka Bani Quraisy,

Fatimah, Sitti, (2016)"Implementasi Manajemen Berbasis Sekolah di SMP Negeri 4 Anggeraja Kab. Enrekang”, Skripsi (Makassar:Fak.Tarbiyah dan Keguruan UIN Alauddin 
Hamalik. Oemar,(2005) Kurikulum dan Pembelajaran, Cet, 5; Jakarta: Bumi Aksara,.

Hadi. Sutrisno, (2002) Metode Reseach Jilid II. Yogyakarta: Andi Offset.

Hasbullah, (2007) Otonomi Pendidikan, (Cet. I; Jakarta; PT. RajaGrafindo Persada:.

Hadari Nawawi,(2003) Kepemimpinan Mengefektifkan Organisasi,Yogyakarta: Gadjah Mada Univercity Press. Handoko .T. Hani, (2003) Manajemen, Cet. ke-18;Yogyakarta: BPFE-Yogyakarta

Herna, wakasek, Wawancara, Tgl 2 Agustus 2018 di MTs Madani Alauddin Pao-pao Kabupaten Gowa.

Imron. Arifin, (2007) Penelitian Kualitatif dalam Ilmu-ilmu Sosial dan Keagaman Malang: Kalimasahada.

Jihad. Asep, (2008) Evaluasi Pembelajaran, Cet, I; Yogyakarta;Multi Pressindo.

Lewis Dkk, (2004) Managemen; Challenge For Tumorrow's Leaders, Cet, IV; Thompson Sounth Wetem.

Mulyasa. E, (2004) Manajemen Berbasis Sekolah, Cet, VII; PT. Remaja Rosdakarya.

Marzuki, (2003) Metodologi Riset .Yogyakarta: BPFE-UII.

Namaduddin, dan Rozikun,Ahmad, Strategi Perencanaan Manajemen Berbasis Madrasah ditingkeat Madrasah, Cet. II, Jakarta: PT Liska Fariska Putra.

Nasution. S, (2007) Metode Penelitian Naturalistik Kualitatif. Bandung; Tarsito.

Rajab. Abdul,kepala sekolah ,W awancara, Tgl 2 Agustus 2018 di MTs Madani Alauddin Pao-pao Kabupaten Gowa 
Sagala,Saiful, (2007) Manajemen Strtategik dalam Peningkatan Mutu Pendidikan, (Cet, II; Bandung; Alfabeta.

Saprin, Unit Sapras, Wawancara, Tgl 2 Agustus 2018 di MTs

Madani Alauddin Pao-pao Kabupaten Gowa.

Sudjono. Anas(2001) Pengantar Evaluasi Pendidikan, Cet, III; Jakarta: Raja Grafindo Persada.

Syah. Muhibbin (2000)Psikologis Belajar, Ed. Revisi 7; Jakarta:

PT. Raja Grafindo persada.

Sudjana. Nana Sudjana, ( 2010) Penilaian Hasil Proses

Pembelajaran. Bandung: PT. Ramaja Rosdakarya.

Suryabrata, Sumadi, (2004) Psikologi Pendidikan. (Cet. XII; Jakarta: PT. RajaGrafindo Persada.

Suparlan, (2013)Manajemen Berbasis Sekolah; dari Teori Sampai Dengan Praktek, Jakarta: PT. Bumi Aksara.

Suparman, Eman, (2002)Manajemen Pendidikan Masa Depan, Jakarta: Balitbang Dikdasmen Depdikbut.

Supriono S(2001) Manajemen Berbasis Sekolah, Cet, I; Jakarta: SIC.

Sugiyono (2009). Metode Penelitian Kualitatif Kuantitatif Dan R\&D, Cet. IV; Bandung: Alfabeta.

Surakhmad. Winarno,(2003) Pengantar Interaksi MengajarBelajar, Bandung: Tarsito,

Siagian, Sondang,( 1997), Filsafat Administrasi, Jakarta: Gunung Agung.

Shihab, M. Quraish,( 2002), Tafsir al-Misbah, Pesan, Kesan dan Keserasian al-Qur'an, Jakarta: Lentera Hati. 
Tim Dosen Administrasi Pendidikan Universitas Pendidikan Indonesia, (2009), Manajemen Pendidikan,Cet.IV; Bandung: AlFabeta.

Umar. Husein,( 2005.) Metode Penelitian Untuk Skripsi dan Tesis Bisnis, Jakarta: PT. Raja Grafindo Persada

Wirartha. I Made, (2006), Metode Penelitian Sosial Ekonomi (Yogyakarta: Andi Offset,.

Yusuf. Muri,( 2014), Metode Penelitian Kuantitatif, Kualitatif \& Gabungan.Cet. I; Jakarta: Fajar Interpratama Mandiri. 